\title{
BRAAUS :DIDS
}

An identification guide to the birds of Great Britain and Ireland

Rob Hume, Robert StIl, Andy Swash, Hugh Harrop and David Tipling

Consultants Chris Batsy

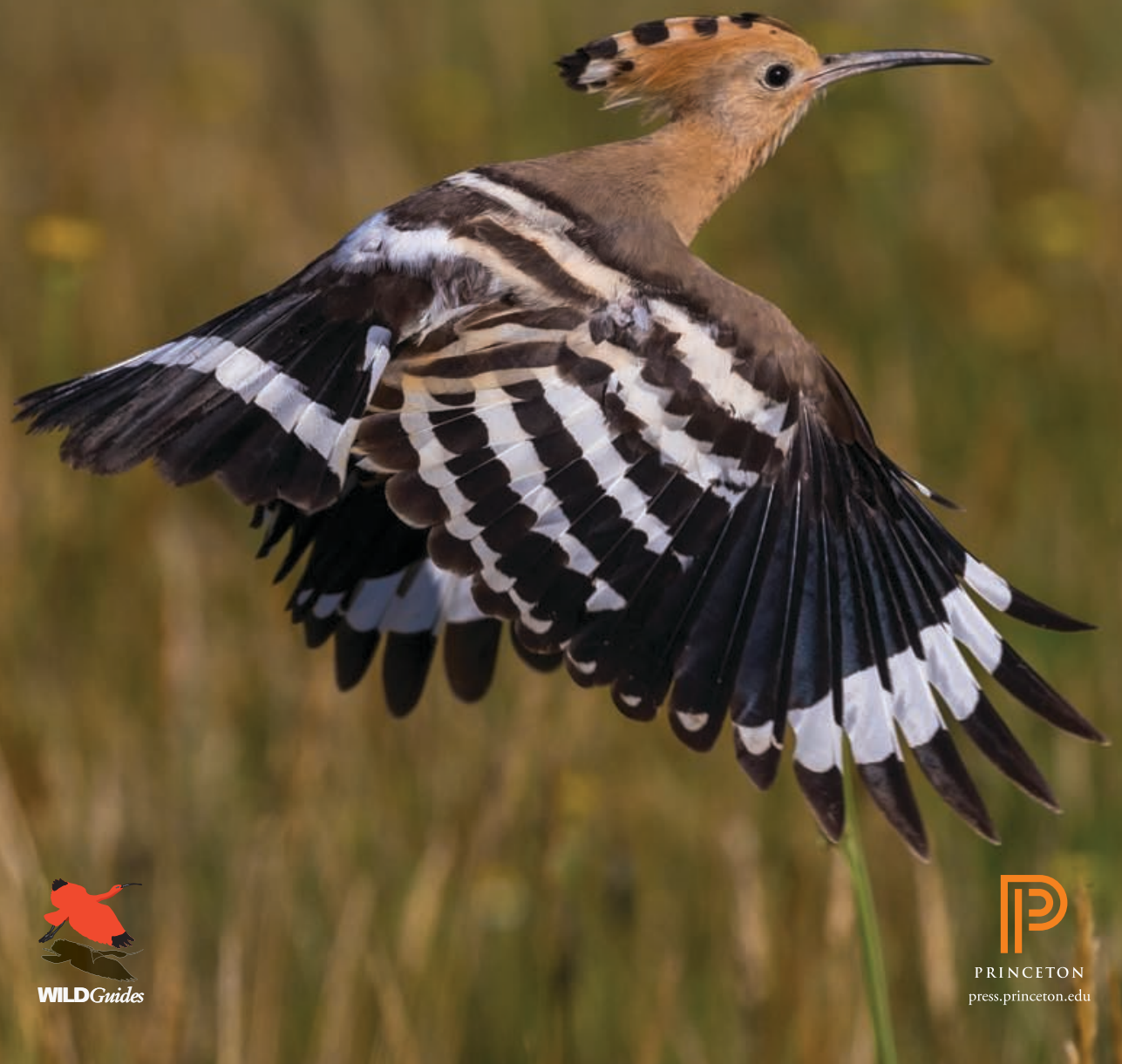


Published by Princeton University Press,

41 William Street, Princeton, New Jersey 08540

In the United Kingdom: Princeton University Press, 6 Oxford Street,

Woodstock, Oxfordshire OX20 1TR

press.princeton.edu

Requests for permission to reproduce material from this work should be sent to

Permissions, Princeton University Press

First published 2016

2nd Edition 2020

Copyright @ 2016, 2020 Princeton University Press

Copyright in the photographs remains with the individual photographers.

All rights reserved. No part of this publication may be reproduced, stored in a retrieval system, or transmitted, in any form or by any means, electronic, mechanical, photocopying, recording, or otherwise, without the prior permission of the publishers.

British Library Cataloging-in-Publication Data is available

Library of Congress Control Number 2020930980

ISBN 978-0-691-19979-5

Production and design by WILDGuides Ltd., Old Basing, Hampshire UK.

Printed in Italy

Published under license from RSPB Sales Ltd. to raise awareness of the Royal Society for the Protection of Birds (Charity registration England and Wales no 207076, Scotland SC037654). For all items sold Princeton University Press will donate a minimum of 40 pence to RSPB Sales Ltd, the trading subsidiary of the RSPB. All subsequent sellers of this book are not commercial participators for the purpose of Part II of the Charities Act 1992.

www.rspb.org.uk

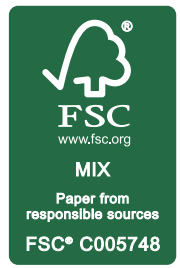

